\title{
Hutan Adat dan Kelas Menengah: Titik Balik Reforma Agraria di Indonesia?
}

Iskandar Zulkarnain

Dosen Sosiologi FISIP Universitas Bangka Belitung

\begin{abstract}
The turning point of the agrarian reform of the customary forest arena after the Constitutional Court's Decision 35/PUU-X/2012 can not be based on state domination (government) through the agenda of territorialization of the forest and not on AMAN as representation of indigenous struggle from the paradox of interest. Bringing the alternative of a critical new middle class, as well as running a deliberation democracy through representational politics that combine extra parliamentary and intra-parliamentary struggles simultaneously in organizational form, capable of realizing sustainable agrarian reform. The new middle class struggle is a synthesis of the dialectic of forest recognition and the existence of indigenous peoples undergoing involution.
\end{abstract}

Keywords: customary forest, domination, agrarian reform, new middle class, deliberation 


\section{A. Pendahuluan}

Praktek teritorialisasi penguasaan negara atas tanah masyarakat adat Indonesia sejak kekuasaan Orde Baru hingga era reformasi menyisakan persoalan kompleks yang berdimensi sosial, ekonomi, dan politik. Secara sosial, teritorialisasi negara menyebabkan penderitaan akibat dimasukkannya seluruh atau sebagian dari wilayah adat dalam kawasan hutan negara yang berdampak terhadap praktik eksklusi sosial, diskriminasi dan berujung pada konflik tenurial yang berkepanjangan (Rachman, 2014). Secara ekonomi, aparatur negara mengeluarkan berbagai lisensi usaha kehutanan yang menguasai luasan tanah dan mengusahakan hutan dalam skala sangat besar, mengakibatkan masyarakat adat terpinggirkan dari arena perebutan sumber daya alam. Akibatnya, pengakuan keberadaan masyarakat adat secara politik terganjal oleh kebijakan institusionalisasi hutan politik.

Perjuangan masyarakat adat di Indonesia untuk mendapatkan kedaulatan atas hutan adat mulai menemukan titik terang pasca dikeluarkannya Putusan Mahkamah Konstitusi Nomor 35/PUUX/2012 (selanjutnya disebut Putusan MK 35) yang intinya menyangkut dua hal, yaitu mengenai konstitusionalitas hutan adat dan pengakuan bersyarat terhadap keberadaan masyarakat adat. Akan tetapi, terbitnya Putusan MK 35 tidak serta merta mengubah keadaan ke arah yang lebih baik. Masalahnya, realisasi Putusan MK 35 masih tersandera oleh "proses lanjutan" agar keputusan hukum ini operasional. "Proses lanjutan" ini memungkinkan terbukanya peluang bagi arena politik lain yang harus dihadapi oleh gerakan masyarakat adat (Savitri, 2014). Arena politik lain memiliki kemampuan memutarbalikkan politik rekognisi dan redistribusi menjadi kekuatan yang mengeksklusi atau membatasi akses dan menyediakan jalan bagi perluasan hegemoni budaya korporasi yang berpeluang mereproduksi ketidakadilan.

Gejala munculnya arena politik lain mulai terasa pasca Putusan MK 35 yang tetap terganjal oleh adanya pasal 67 ayat (2) yang mengharuskan terpenuhinya sejumlah syarat sebelum "hutan adat" tersebut diakui. Sejumlah persyaratan itu selaras dengan rumusan UUD 1945 pasal 18B ayat (2) dengan frasa "sepanjang masih hidup dan diakui keberadaannya". Merujuk pada kesamaan frasa yang intinya "hutan adat" dapat diakui setelah persyaratan pengakuan itu diatur lebih lanjut dalam peraturan daerah (Perda) yang ditetapkan oleh DPRD setempat. Arena kelembagaan mulai memainkan politiknya dengan disahkannya UU Nomor 6 tahun 
2014 tentang Desa yang memberi ruang bagi kelembagaan desa adat dan terbitnya Peraturan Menteri Dalam Negeri Nomor 52 tahun 2014 tentang Pedoman Pengakuan dan Perlindungan Masyarakat Hukum Adat. Di sisi lain, Aliansi Masyarakat Adat Nusantara (AMAN) yang memperjuangkan "konsep pengakuan yang dicita-citakan" yang intinya tidak menghendaki adanya sejumlah persyaratan pengakuan. AMAN terus berjuang untuk pengakuan dan perlindungan masyarakat hukum adat dengan mengajukan Naskah Akademik Rancangan Undang-undang Pengakuan dan Perlindungan Masyarakat Hukum Adat (RUU PPMHA) sebagai tandingan ke DPR RI.

Di tengah perdebatan struktur agraria yang sangat dinamis pasca Putusan MK 35 terutama menyangkut siapa yang berhak (tenurial institution) dan untuk kepentingan apa hutan adat itu diperuntukkan di masa mendatang menjadi relevan untuk dikaji lebih lanjut. Pertanyaan yang dapat dikemukakan adalah kelembagaan mana yang berperan mengisi kekosongan ruang politik di tengah ancaman kepentingan "politik lain" dan terjadinya arena mengambang (floating field)? Sejauhmana kelembagaan baru dapat mengisi ruang politik itu untuk kemudian bergerak menuju tercapainya pembaruan agraria dari arena hutan adat?

\section{B. Kerangka Teoretis}

Fenomena hutan adat dan jalannya mainstream konservatif negara dapat dianalisa menggunakan terminologi Antonio Gramsci tentang hegemoni. Konsep hegemoni Gramsci (lihat Arief dan Patria, 2009) menyatakan bahwa agar kekuasaan dapat langgeng membutuhkan paling tidak dua perangkat kerja. Pertama, perangkat kerja yang mampu melakukan tindak kekerasan yang bersifat memaksa atau dengan kata lain kekuasaan membutuhkan perangkat kerja yang bernuansa law enforcemant. Kedua, perangkat kerja yang mampu membujuk masyarakat beserta pranata-pranata untuk taat pada mereka yang berkuasa melalui kehidupan beragama, pendidikan, kesenian dan bahkan juga keluarga.

Dalam penjelasan yang lebih mendalam, kekuasaan bekerja melampaui cara-cara hegemonik, yang mana hal ini dikonsepsikan Foucault sebagai governmentality (Merlingen, 2006). Foucault melihat bahwa pemerintahan sejatinya tidak dilihat hanya sebagai institusi politico-birokratik yang mengatur masyarakat, tetapi perlu dilihat dalam dimensinya sebagai 'cara mengoperasikan kekuasaan'.

Terkait kemunculan kelembagaan “politik" kelas menengah yang digadang- 
gadang sebagai agen pengubah, digunakan konsep tindakan komunikatif Jurgen Habermas, yaitu komunikasi lewat argumentasi (bahasa) berupa diskursus maupun kritik (Hardiman, 2009). Tindakan komunikatif mengharuskan seseorang memperoleh kompetensi komunikatif yang mendisposisikan segenap komunikasi yang mengacu pada dunia kehidupan dan sistem (Suseno, 2004). Dunia kehidupan merepresentasikan ia hidup dalam sebuah alam bermakna yang dimiliki bersama dengan komunitasnya yang terdiri atas pandangan dunia, keyakinan-keyakinan moral dan nilai-nilai bersama. Disisi lain, masyarakat juga merupakan sistem. Ia adalah segala macam institusi dan peraturan yang menata kehidupan masyarakat. Tujuan sistemisasi adalah meringankan beban komunikasi yang salah satunya melalui hukum dan politik. Agar hukum dapat menjalankan fungsi politisnya, diperlukan demokrasi deliberatif di mana legitimitas hukum tercapai karena hukum lahir dari diskursus-diskursus dalam masyarakat sipil. Menurut Habermas, dalam demokrasi deliberatif perundangan dipengaruhi oleh diskursus-diskurus "liar" yang terjadi dalam masyarakat dipicu oleh kekuasaan administratif (negara) dan kekuasaan ekonomi (uang).

\section{Pembahasan dan Analisis}

\section{Retorika Konservatif}

Hambatan pada "proses lanjutan" pasca Putusan MK 35 yang mengharuskan terpenuhinya persyaratan-persyaratan sebelum hutan adat dapat diakui secara konstitusional menunjukkan bahwa terjadi pemusatan kontrol negara dengan menggunakan retorika populis yang sekedar kamuflase ke pelanggengan mainstream konservatif dari rezim sebelumnya (White, 2006). Mainstream konservatif lanjut Ben White tidak mempunyai basis sosial atau komitmen yang kuat bagi berlangsungnya perubahan sosial yang mendasar di pedesaan. Akibatnya, mainstream konservatif sebagai pemegang kekuasaan akan selalu berhadapan dengan komunitas intelektual yang memiliki pengetahuan langsung tentang kondisi lapangan dan pengetahuan komparatif tentang fenomena di negara lain, sehingga mereka hadir sebagai pengkritik kebijakan agraria yang sedang dijalankan beserta dampaknya.

Pelanggengan mainstream konservatif atas kebijakan agraria salah satunya terkait hutan adat dan rekognisi masyarakat adat dijalankan atas dasar hegemoni kekuasaan. Menurut Siscawati (2014) terdapat empat faktor kuasa yang memberikan kontribusi penting dalam 
proses mengeksklusi pihak lain dari akses terhadap tanah, yaitu: regulasi, pemaksaan dengan kekerasan, pasar, dan legitimasi. Dedi Gustian (Gustian, tt) dalam tulisannya "Teritorialisasi dan Perubahan Ruang Kehidupan Rakyat", ingin menunjukkan bahwa praktek penguasaan ruang komunitas di sekitar hutan tidak dapat dipisahkan dari agenda "pembangunan" kawasan melalui proses pengaturan, koreksi perencanaan ruang, dan mereproduksi ruang dengan aturan yang selalu berubah-ubah. Proses pengaturan ini dianggap sebagai "upaya membatasi akses sekaligus memutus (sejarah) hubungan tradisional penduduk terhadap sumber-sumber agraria yang menjadi sumber penghidupan utama". Penelitian Yusriadi (2010) tentang industrialisasi dan perubahan fungsi sosial hak milik atas tanah, menyatakan bahwa pembebasan tanah atas nama industrialisasi telah menyebabkan munculnya berbagai konflik sosial yang terjadi secara sistematis. Berawal dari penggunaan kekuasaan dan kewenangan lembaga oleh aparatur, selanjutnya diaktualisasikan untuk kepentingan pengusaha (korporasi). Dalam perkembangannya melahirkan orientasi baru dalam strategi kebijakan pengadaan tanah, yakni "pembentukan pasar tanah yang efisien dengan mempersatukan aliansi antara state bureaucrats, client businessman, foreigh investors, dan professionals". Aliansi sekutu yang telah terbentuk dan bekerja dalam sistem, berdampak pada terabainya ide-ide kritis dan romantis tentang hak-hak "komunitas" seperti masyarakat adat (White, 2006).

Apa yang terjadi pada proses pengakuan hutan adat di Indonesia yang melalui proses transisi yang begitu panjang mengutip Budi Baik Siregar (Siregar, 2001) dan Maria Rita Roewiastoeti (Roewiastoeti, 2014) sebagai bentuk respons politik ketakutan pemerintah dan legislator yang berlebihan. Politik ketakutan pemerintah dijalankan dengan mengandalkan politik masa mengambang (floating mass) yang bekerja di bawah patron politik pembangunan dengan menempatkan lembaga-lembaga pemerintahan yang berdigdaya untuk menjalankan politik lokal terutama di pedesaan. Tujuan utamanya adalah menghambat munculnya institusi sosial lain yang lebih progresif dan kritis yang akan mengancam kepentingan dominasi kekuasaan beserta kroninya. Organisasi Karang Taruna, PKK, Kelompok Tani, Kelompok Nelayan dijadikan alat untuk mengisi ruang politik desa. Di tingkat legislatif, menurut Roewiastoeti merumuskan beberapa persyaratan dengan 
menempatkan frasa "sepanjang masih hidup dan diakui keberadaannya" dalam UU nomor 5 Tahun 1960 Pasal 3, UU Nomor 41 Tahun 1999 Pasal 4 ayat (3), dan UUD 1945 Pasal 18B ayat (2) hasil amandemen, berdampak pada terhambatnya pengakuan hutan adat dan eksistensi masyarakat adat, karena kelompok ini harus diatur lebih lanjut dalam peraturan daerah yang ditetapkan oleh DPRD setempat.

Gejala politik ketakutan ini menandai terjadinya kesenjangan struktural dari peluang politik yang dibuka oleh Putusan MK 35 dimungkinkan kemunculannya dari keharusan gerakan masyarakat adat untuk menghadapi ragam arena politik lain sebagai "proses lanjutan" dari Putusan MK 35. Dari arena politik lain itu akan mengarah pada pembentukan arena dan struktur baru yang tidak diprediksi, namun sangat mungkin terjadi. Menurut Savitri (2014), terdapat tiga struktur baru yang terbentuk. Struktur pertama, teknikalisasi melalui regulasi. Melalui regulasi akan memaksa masyarakat adat untuk mengukuhkan keberadaannya sebagai subjek hukum melalui Perda dan setelahnya mekanisme privatisasi hak atas properti (tanah) mengalami pengalihan: dari tanggung jawab negara menjadi tanggung jawab individu, kelompok komunitas, atau bahkan korporasi. Inilah yang disebut oleh Li sebagai "privatisasi tanggung jawab" (Li, 2000); menurut Yusriyadi (2010) sebagai state bureaucrats; dan menurut Ben White (White, 2006) sebagai mekanisme halus perampasan hak-hak "komunitas".

Kedua, pengaturan pemilikan dan penguasaan "hutan adat" akan jatuh pada korporasi akibat keterbelahan antara kepengaturan dalam bentuk komunalisasi atau privatisasi. Masyarakat adat atau rakyat pedesaan setiap hari akan berhadapan dengan paksaan pasar yang memerasnya habis-habisan. Ketiga, kepengaturan hutan adat oleh korporasi membuka kesempatan akan hadirnya elitisisme dan ketidakadilan yang sifatnya inheren dalam kepengaturan neoliberal.

Berjalannya struktur agraria yang timpang serta pelanggengan mainstream konservatif mengutip Gunawan Wiradi (Wiradi, 2000), telah menyebabkan negara gagal melakukan reforma agraria. Kegagalan reforma agraria itu lebih disebabkan oleh tidak adanya keinginan politik (political will) dari penguasa untuk menuntaskan problem keagrariaan yang berpihak pada kepentingan rakyat dan sebagian besar elit nasional merupakan "businessman" yang tentu berkepentingan terhadap kepentingan agraria dengan cara berkompromi terhadap pemilik modal 
yang mengendalikan industri dan mekanisme komodifikasi tanah. Merujuk pandangan Wiradi, dalam konteks hutan adat ini proses jalannya reforma agraria by gress (dari negara melalui kebijakan) dan by levridge (organisasi mandiri masyarakat) tidak menemukan titik temu.

Fenomena hutan adat dan jalannya mainstream konservatif negara menandai terjadinya praktik-praktik hegemoni negara melalui perangkat kerja law enforcemant seperti hukum (peraturan, regulasi, kebijakan) yang mampu melakukan tindakan kekerasan yang bersifat memaksa. Kebijakan pemberian izin prinsip, izin lokasi, dan hak guna usaha (HGU) kepada korporasi besar yang beroperasi di sektor pertambangan dan perkebunan semakin mempercepat terlaksananya program perampasan tanah ulayat dan hutan adat dari penguasaan komunal masyarakat adat. Menurut Furnivall, peraturan-peraturan yang berlaku sebenarnya bukanlah peraturan baru, tetapi peraturan-peraturan yang diturunkan dari Agrarischewet, turut membantu percepatan terlaksananya program enclosure di negeri jajahan (Furnivall, 2009). Selain itu, perangkat kerja di tingkat daerah, mulai dari bupati/walikota hingga perangkat terkecil di tingkat desa/dusun memainkan perannya sebagai agen "pembujuk" dan agen perantara dengan menempatkan perangkat kerja di lini-lini strategis guna memuluskan agenda sosialisasi, lobi-lobi, mediasi serta negosiasi dan renegosiasi terkait pembebasan tanah/hutan untuk kepentingan korporasi. Terkadang kumpulan preman dijadikan sebagai agen pembujuk sekaligus pemaksa terhadap warga adat yang tidak ingin menjual, menerima ganti rugi tanam tumbuh (GRTT) atau menyerahkan tanah/lahan untuk kepentingan korporasi.

Fenomena intimidasi dengan memakai govermentality ala Foucault, menunjukkan ketaatan paksa kepada mereka yang berkuasa dengan mengatasnamakan kesejahteraan dan kemakmuran di balik penguasaaan korporasi besar atas tanah ulayat/hutan adat yang sebelumnya dalam penguasaan masyarakat adat. Sementara masyarakat adat ternormalisasi dalam kehidupan sehari-hari, merasa nyaman, tak ada yang aneh, tanpa ada perlawanan atau penolakan. Padahal sesungguhnya, tanpa disadari bahwa ia sedang dipaksa dan dikendalikan.

\section{Titik Balik Kebangkitan Adat}

Reproduksi mainstream konservatif negara terhadap pengakuan bersyarat atas hutan dan masyarakat adat yang menegasikan subjek hukum, menjadi titik balik kebangkitan adat. Menurut Jamie S. 
Davidson, David Henley, dan Sandra Moniaga (Davidson, Henley, Moniaga, 2010) dalam pengantar buku "Adat Dalam Politik Indonesia" menyebutkan kebangkitan adat tidak pernah diprediksi sebelumnya oleh para peneliti tentang Indonesia dan masih kurang mendapat perhatian ilmiah. Menurut Yance Arizona (Arizona, 2011) terdapat empat faktor utama kebangkitan adat di Indonesia. Pertama, kebangkitan adat merupakan kontribusi dari perkembangan wacana dan dorongan dari organisasi-organisasi internasional. Serangkaian perkembangan ini menunjukan bahwa kebangkitan adat adalah sesuatu yang nyata dan mendunia. Organisasi masyarakat adat seperti AMAN terlibat menjadi bagian organisasi advokasi hak-hak masyarakat adat internasional seperti IWGIA dan AIPP (Asian Indigenous People Pact) yang tidak saja terlibat dalam kegiatan level internasional tetapi juga menjadi "tuan rumah" bagi para sarjana dan aktivis luar negeri yang membahas soal masyarakat adat.

Kedua, faktor tekanan dan penindasan di bawah Orde Baru. Gerakan masyarakat adat yang bangkit di Indonesia beranjak dari satu asumsi kesadaran bersama bahwa mereka adalah korban dari program-program pembangunan selama Orde Baru berkuasa. Ketiga, faktor keterbukaan pasca Orde Baru. Runtuhnya Orde Baru membuka ruang keterlibatan massa yang massif di Indonesia. Keempat, warisan ideologis dari pemikir hukum adat pada masa kolonial. Warisan ideologis dari kolonial dalam kajian adat salah satunya adalah sumbangsih dari Cornelis Van Vollenhoven, profesor di Universitas Leiden sejak tahun 1909 dan bapak dari 'Leiden School' yang melahirkan konsepkonsep kunci dalam wacana adat sampai saat ini. Konsep-konsep tersebut seperti hukum adat (adatrecht), beschickingrecht yang dipadankan dengan hak ulayat dan juga masyarakat hukum adat (adatrechtgemeenschap) yang masih melekat kuat dalam diskursus adat di Indonesia.

Peluang-peluang yang terbuka pasca Orde Baru inilah yang dimanfaatkan oleh aktivis masyarakat adat untuk mendirikan AMAN pada tahun 1999 yang menjadi simbol perubahan radikal yang sedang terjadi. Dalam kongres pertamanya tahun 1999 menggema tuntutan 'bila negara tidak mengakui kami, maka kami tidak akan mengakui negara.' Tuntutan itu sebenarnya mencerminkan karakter khas dari gerakan masyarakat adat kontemporer yang ingin dihargai sebagai bagian dari negara, bukan malah bertujuan memisahkan diri (separation) dari negara. 
Seiring perjalanan waktu, perjuangan AMAN kian diperhitungkan dalam arena ruang politik di era reformasi. Salah satunya adalah dengan mengajukan gugatan bersama dua anggota AMAN yakni Kesatuan Masyarakat Hukum Adat Kenegerian Kuntu dan Kesatuan Masyarakat Hukum Adat Kasepuhan Cisitu. Mereka memohon MK menguji konstitusionalitas Pasal 1 angka 6 dan beberapa pasal lainnya dalam UU No. 41 Tahun 1999 yang berakhir dengan dikabulkanya sebagian gugatan oleh MK yang tertera dalam Putusan MK 35 yang dibacakan pada 16 Mei 2013. Sejak tanggal dibacakan itu, hutan adat bukan lagi bagian dari hutan negara yang berada di bawah penguasaan Kementerian Kehutanan (Rachman, 2014).

Pasca Putusan MK 35 yang menandai adanya pengakuan bersyarat sebelum hutan adat dan amsyarakat adat diakui oleh konstitusi seperti tertera pada Pasal 18B ayat (2) UUD 1945 sebagai salah satu landasan konstitusional masyarakat adat, menyatakan pengakuan secara deklaratif bahwa negara mengakui dan menghormati keberadaan dan hak-hak masyarakat adat. Pasal 18B ayat (2) UUD 1945 berbunyi: Negara mengakui dan menghormati kesatuan-kesatuan masyarakat hukum adat serta hak-hak tradisonalnya sepanjang masih hidup dan sesuai dengan perkembangan masyarakat dan prinsip Negara Kesatuan Republik Indonesia, yang diatur dalam undangundang. Namun rumusan pengakuan dalam ketentuan tersebut memberikan batasan-batasan atau persyaratan agar suatu komunitas dapat diakui keberadaan sebagai masyarakat adat. Ada empat persyaratan keberadaan masyarakat adat menurut Pasal 18B ayat (2) UUD 1945 antara lain: (a) sepanjang masih hidup; (b) sesuai dengan perkembangan masyarakat; (c) Prinsip Negara Kesatuan Republik Indonesia; (d) Diatur dalam undangundang.

Terkait persyaratan pengakuan tersebut, AMAN beserta jejaring kerjanya mengajukan Naskah Akademik RUU PPMHA yang secara substansi mencantumkan antara lain: Pertama, penolakan terhadap hak yang bersifat berian (hak berian) oleh negara, karena esensi masyarakat adat adalah terlekat hak bawaan. Kedua, melakukan oto-kritik terhadap pengakuan bersyarat. Ketiga, masyarakat adat memang sejak semula sudah menerapkan teori otonomi. Dan penerapan teori otonom ini semakin nyata ketika komunitas masyarakat adat mempergunakan hak-hak komunitas dalam pengelolaan berbagai sumber daya alam seperti hak ulayat. Dengan demikian, jika otonomi daerah kemudian diterjemahkan 
dalam pengertian kemandirian, maka bagi masyarakat adat kemandirian ini telah tertanam dalam kearifan-kearifan lokal yang telah mereka miliki selama bertahuntahun.

Gerakan AMAN dalam bentuk artikulasi kepentingan perjuangan masyarakat adat terus digaungkan. Akan tetapi, dalam setiap gerakan tentu tidak terlepas dari adanya paradoks-paradoks dalam isu perjuangan adat kontemporer. Paradoks itu antara lain: pertama, gerakan AMAN beserta jejaring kerjanya dalam spektrum politik adat saat ini mengambil bentuk yang paradoksal sebagai konservatisme radikal yang vis-a-vis dengan negara sehingga dianggap sebagai penentang ideologi pembangunan agraria. Kedua, terkait orientasi gerakan, konteks apa dan siapa yang sebenarnya sedang diperjuangkan serta apa dan siapa yang seharusnya tidak diperjuangkan, menjadi paradoks yang sampai saat ini belum dirumuskan secara transparan terutama Ornop yang dianggap project minded. Dalam hal ini masih terdapat asumsi bahwa masyarakat adat sering dijadikan instrumen program oleh Ornop. Selain itu, terdapat kecenderungan memanfaatkan isu masyarakat adat untuk melegitimasi kembalinya feodalisme serta kemana orientasi ornop apakah uang, lembaganya sendiri atau masyarakat adat. Ketiga,
AMAN dan ornop terjebak dalam politik aliran yang mengedepankan isu etnisitas sebagai basis perjuangan, bukan dari isu kelas. Menurut Sangaji (2010) gerakan masyarakat adat hendaknya menjadikan identitas etnik sebagai titik tolak, tetapi mengartikulasikannya tidak dengan semangat etnosentrik. Keempat, terkait organisasi gerakan, AMAN dipandang sebagai "penyelamat" bagi masyarakat adat, sehingga menimbulkan ketergantungan yang besar terhadap perjuangan adat. Selain itu, belum berkembangnya hubungan yang sinergis secara berkelanjutan antara masyarakat adat dan ornop (Kedai, 2001).

Paradoks-paradoks tersebut menjadi tantangan tersendiri bagi AMAN untuk memperbaiki relasi dengan negara. Dalam sambutan 17 Tahun Kebangkitan Masyarakat Adat Sekretaris Jendral AMAN, Abdon Nababan, menyampaikan sambutan yang menyatakan bahwa saat ini AMAN selalu dilibatkan dalam merencanakan sesuatu berkaitan dengan adat. AMAN sudah mulai didengar. Tapi apakah didengar dan kemudian diterjemahkan menjadi kebijakan? Apakah perjuangan AMAN akan mulus dalam mengawal isu politik ini?

\section{Peran Kelas Menengah Baru?}

Situasi paradoksal gerakan masyarakat adat yang direpresentasikan 
oleh AMAN beserta jejaring kerjanya menjadi lingkaran setan yang memperlambat gerak langkah pergerakan ornop. Di tengah melambatnya gerakan sangat dimungkinkan arena kelembagaan negara yang konservatif mengeluarkan kebijakan monopoli untuk menerapkan politisasi hutan adat atas nama pembangunan berkelanjutan. Berbekal Peraturan Menteri Dalam Negeri No. 52 Tahun 2014 tentang Pedoman Pengakuan dan Perlindungan Masyarakat Hukum Adat dapat terjadi pembelokan politik (deviasi) dengan memanipulasi keabsahan suatu komunitas atau masyarakat adat sebagai subjek hukum adat berdasarkan empat persyaratan UUD 1945 Pasal 18B ayat 2. Jika ini terjadi dan identitas penyandang subjek hukum adat dilucuti, siapa yang berhak atas kepemilikan hutan adat?

Antisipasi terjadinya gejala deviasi politik terhadap Putusan MK 35 sudah saatnya diperlukan sebuah kekuatan politik kelas menengah sebagai penyeimbang kekuatan Ornop seperti AMAN dan jejaring kerjanya. Penggunaan istilah kelas menengah memang berbeda-beda. Menurut Farchan Bulkin (Dalam Aziz, 2016) golongan menengah adalah kelompok sosial dalam masyarakat yang terdiri dari kaum intelektual, mahasiswa, pemimpin surat kabar, kaum pengusaha, pedagang pribumi, ahli hukum dan kelompok-kelompok profesional. Perspektif yang digunakan adalah perspektif ketergantungan. Menurut Alavi (Dalam Jati, 2015) kelas menengah sebenarnya berwujud kelas politik ekstra parlementer yang memainkan peran mediasi terhadap kelas penguasa (governing elite) dengan kelas masyarakat lainnya (non-governing elite). Pengertian ini selaras dengan teorema no bourgeoisie no democracy yang disampaikan oleh Barrington Moore (Moore, 1956) di mana proses pertumbuhan dan perkembangan ekonomi masif akan berimplikasi simetris pada pertumbuhan politik juga. Pengertian lain muncul dari perspektif Max Weber (dalam Seda, 2012) berpendapat bahwa ukuran kelas menengah dapat dilihat dari segi pendapatan, pendidikan, status sosial, dan hal-hal lain yang dapat dikuantifikasi.

Merujuk pengertian kelas menengah yang disampaikan Alavi dan Moore, membincangkan peran legislator di era demokrasi serta mengkaitkannya dengan perjuangan hutan adat dan masyarakat adat pasca Putusan MK 35 tentu menemukan relevansinya. Relevansinya berkait erat dengan beberapa premis berikut: pertama, persoalan legislasi (pembuatan undangundang) merupakan pokok masalah yang mengakibatkan sengkarut yang berkepanjangan pasca Putusan MK 35. 
Quantum legislation harus menjembatani kedua kelembagaan (negara dan Ornop) melalui percepatan pembahasan undangundang tersendiri yang menyerap aspirasi publik. Kedua, parlemen merupakan representasi dari rakyat seharusnya berani melakukan tekanan politik terhadap legislator yang memiliki ketakutan yang berlebihan dan berkepentingan terhadap kapitalisasi hutan adat. Ketiga, konsolidasi legislator dari kelas menengah yang terdidik, peduli, dan kritis (nonbusinessman) menjadi kekuatan baru sebagai agen pengawal legislasi serta melawan kapitalisme agraria (hutan adat). Keempat, kekosongan produk legislasi dalam waktu yang tidak menentu akan berimplikasi secara sosial politik yang mengakibatkan kebingungan dan ketidakpastian di tingkat daerah dan di internal komunitas adat. Bagaimana legislator di tingkat pusat dan di daerah memainkan peran kelas menengahnya?

Mengacu pada tindakan komunikatif Jurgen Habermas yang dielaborasi dengan demokrasi deliberatif, mewacanakan legislator sebagai agen pengubah kekuasaan sekaligus perlawanan yang sistemik dan terorganisir merupakan suatu terobosan progresif. Peran legislator sebagai mediator yang kritis terhadap kelas penguasa (governing elite) dengan kelas masyarakat lainnya (non-governing elite), dalam konteks ini menjembatani kaum intelektual, profesional, Ornop (AMAN beserta jejaring kerja) dan masyarakat adat merupakan suatu keniscayaan. Peran mediator sekaligus menjalankan fungsi agregasi dan artikulasi kepentingan serta penekan perlu dilakukan dalam mengawal perumusan dan penetapan perundangundangan terkait hutan dan masyarakat adat sejak awal hingga tuntas. Dengan mengintegrasikan peran dan fungsi kelas menengah yang peduli dan kritis tersebut serta terkonsolidasi ke dalam jaring-jaring komunikasi publik masyarakat sipil dengan sendiri akan membentuk kekuasaan komunikatif. Kekuasaan komunikatif ini akan dimainkan melalui media, pers, lembaga swadaya masyarakat (LSM), dan organisasi-organisasi lain yang seakan-akan mengepung sistem politik sehingga responsif terhadap diskursusdiskursus hutan dan masyarakat adat. Disisi lain, masyarakat sipil di tingkat lokal dapat mengembangkan kekuasaan komunikatifnya melalui hak menyatakan pendapat secara terbuka (public opinion). Kekuasaan komunikatif masyarakat sipil tidak dapat menguasai sistem politik, namun dapat mengarahkan keputusankeputusannya. Sedangkan kekuasaan komunikatif legislator memungkinkan untuk menguasai sistem politik dalam bentuk penguasaan arena dan tekanan- 
tekanan terhadap partai politik serta lobilobi politik yang berpihak kepada kepentingan masyarakat adat. Tekanantekanan yang terakumulasi dari jalur 'atas' dan jalur 'bawah' yang memusatkan energi pada upaya meruntuhkan dominasi negara, akan melahirkan akumulasi tekanan yang berbasis pada tekanan-tekanan secara kolektif pada waktu, ruang, cara dan tujuan yang sama.

Belajar dari pengalaman perjuangan masyarakat adat di Canada, mengutip Jeff Corntassel dari University of Victoria Canada (Corntassel, 2012), di mana masyarakat adat berupaya keluar dari jerat kolonisasi negara dengan perjuangan melalui upaya meninjau ulang pemahaman dan kebijakan terhadap masyarakt adat melalui dua jalur, yaitu dekolonisasi dan membangkitkan kembali teknologi material khazanah kearifan masyarakat adat melalui perjuangan politik parlemen dan restrukturisasi pendidikan. Locus utama perjuangan menitikberatkan pada oto-kritik kebijakan negara menyangkut pemahaman hak, rekonsiliasi, dan sumber daya alam (politic of distraction). Perjuangan politik di parlemen menjadi babak baru bagi diakuinya identitas kultural masyarakat adat beserta wilayah geografisnya sehingga mengakhiri transisi menuju transformasi dekolonisasi dan kebangkitan adat.

\section{Penutup}

Pengalaman di Canada dapat dijadikan diskursus baru bagi perjuangan masyarakat adat di Indonesia yang tengah berjuang mencapai otonominya yang terpasung. Pada satu sisi, berharap banyak kepada negara/pemerintah dan AMAN yang merepresentasikan perjuangan masyarakat adat tidak dapat dikatakan terwakili secara politis mengingat berbagai paradoksal yang mengemuka. Di sisi yang lain, munculnya ruang politik pasca Putusan MK 35 memberi peluang bagi kelas menengah baru untuk menjalankan deliberasi nilai-nilai baru seperti egalitarian dan partisipatoris. Deliberasi dijalankan melalui politik representasi dengan membentuk kekuasaan komunikatif dan akumulasi tekanan yang terkonsolidasi dan bertransformasi menjadi kelas politik yang memadukan perjuangan ekstra parlementer dan intra parlementer secara bersamaan dalam bentuk organisatoris, sehingga mampu menampilkan diri sebagai kelompok penekan demi kepentingan masyarakat adat.

Data AMAN per Maret 2015 tercatat 2.244 komunitas adat yang tersebar di pelosok tanah air dengan total populasi sekitar 17 juta orang yang menguasai sekitar 10 juta hektar hutan adat dan 
penelitian Epistema Institute menunjukkan luas wilayah adat yang diakui negara semakin bertambah dari 15.199,16 hektar sebelum Putusan MK 35 menjadi 213.541,01 hektar (Arizona, Malik, Ishimora, 2017). Artinya, harapan terbukanya pembaruan agraria melalui devolusi hutan adat kepada pemiliknya yang sah selaku subjek hukum melalui peran kelas menengah baru dapat terwujud dan mereka akan merasakan resonansi kebangkitan adat di abad ke-21.

Peluang menuju kebangkitan adat dengan menempatkan masyarakat adat sebagai subjek hukum atas hutan adatnya menjadi momentum negara untuk melakukan pembaruan agraria seutuhnya. Sebab masyarakat adat merupakan petani yang dalam istilah van der Ploeg (Ploeg, 2008) disebut sebagai petani yang berkarakter peasant. Peasant adalah yang menggerakkan pertanian. Karakter peasant memenuhi prinsip-prinsip dasar petani kecil, yaitu kelekatan antarelemen yakni menguasai sumber daya alam sendiri, memproduksi secara bersama, berinteraksi antara manusia dan alam, hubungan kerja sama yang memungkinkan petani kecil untuk menjauhkan diri dari hubungan moneter dan pertukaran pasar, perjuangan untuk mencapai otonomi bertujuan untuk mengurangi ketergantungan dan aliansi pertanian yang lebih menguntungkan kepentingan produsen kapitalis. Jika upaya mendorong masyarakat adat menuju repeasantization atas hutan adatnya tidak menemukan titik terang, bandul reforma agraria sedang bergerak menuju involusi agraria berkelanjutan .

\section{Daftar Pustaka}

AMAN, 2011. Naskah Akademik Rancangan Undang-undang Pengakuan dan Perlindungan Masyarakat Hukum Adat. Jakarta: AMAN.

Arief, A dan Patria N, 2009. Antonio Gramsci Negara dan Hegemoni. Yogyakarta: Pustaka Pelajar.

Arizona, Y. Mempertanyakan Kebangkitan Adat. Jurnal Jentera, Edisi 21 Tahun IV Januari-April 2011, hal. 96-102. Arizona, Y, Malik, Ishimora LI. Pengakuan Hukum Terhadap Masyarakat Adat: Tren Produk Hukum Daerah dan Nasional Pasca Putusan MK 35/PUU-X/2012. Outlook Epistema 2017. Jakarta: Epistema Institue.

Aziz, UA. Masyarakat Kelas Menengah Indonesia: Terkurung Dalam Paradigma Kapitalisme Pinggiran. Makalah diakses 8 Oktober 2017 pukul 19.45 WIB.

Corntassel, J. 2012. Re-envisioning Resurgence: Indigenous Pathways to 
Batin Pengambang Jambi). Dalam Politik Ruang dan Perlawanan: Kisah Konflik atas Ruang di Tingkat

Lokal. Bogor: Jaringan Kerja Pemetaan Partisipatif.

Hardiman, B.F, 2009. Mепији Masyarakat Komunikatif. Yogyakarta: Kanisius

Jati, R.W. Mendefinisikan Kelas Menengah. Jurnal Online LIPI www.lipi.go.id Edisi Februari 2015.

Kedai (Kelompok Diskusi Adat Indonesia). Refleksi Gerakan Masyarakat Adat. Hasil Diskusi Bersama AMAN, ELSAM, JAPHAMA, KPSHK dan ICRAF, Bogor 2001.

Li, T.M. 2000. Articulating Indigenous Identity in Indonesia: Resource Politics and the Tribal Slot. Comparative Studies in Society and History 42 (1): 149-179.

Merlingen, M, 2006. Foucault and World Politics: Promises and Challenges of Extending Governmentality Theory to the European and Beyond. Millennium: Journal of International Studies, 2006. ISSN 0305-8298. Vol 35 No 1, pp. 181-196.

Moore J.B, 1973. "Social Origins of Dictatorship and Democracy: Lord and Peasent in the Making of the Modern World".Penguin University Books.
Ploeg, van der DJ, 2008. The New Peasantries Struggle for Autonomy and Sustainability in an Era of Empire and Globalization. London Sterling VA.

Rachman, F.N, Masyarakat Hukum Adat adalah Penyandang Hak, Subjek Hukum, dan Pemilik Wilayah Adat. Jurnal Wacana Nomor 33, Tahun XVI, 2014, hal.25-48.

Sangaji, A. 2010. Kritik terhadap gerakan masyarakat adat di Indonesia. Dalam buku Adat Dalam Politik Indonesia. Jakarta: Yayasan Obor Indonesia dan KITLV Jakarta.

Savitri, L.A, Rentang Batas dari Rekognisi Hutan Adat Dalam Kepengaturan Neoliberal. Jurnal Wacana Nomor 33, Tahun XVI, 2014, hal.61-98.

Seda, F. Kelas Menengah Indonesia: Gambaran Umum Konseptual. Dimuat dalam Jurnal Prisma Vol 31, No 1, Tahun 2012.

Siscawati, M. Pertarungan Penguasaan Hutan dan Perjuangan Perempuan Adat. Jurnal Wacana Nomor 33, Tahun XVI, 2014, hal.159-197.

Siregar, B.B, 2001. Politik Ketakutan Menelusuri Jejak Ketertinggalan Merajut Kerukunan Melintasi Krisis. Bogor: Penerbit P3R-YAE.

Suseno, M.F, 75 Tahun Jurgen Habermas. Majalah Basis No.11-12, Tahun ke- 
53, November-Desember 2004, hal.

4-13.

Wiradi, G, 2000. Reforma Agraria:

Perjalanan yang Belum Berakhir. Yogyakarta: Insist Press.

White, B, 2006. Di Antara Apologia

Diskursus Kritis: Transisi Agraria dan Pelibatan Dunia Ilmiah di Indonesia. Dalam Buku Ilmu Sosial dan Kekuasaan di Indonesia. Jakarta: PT Equinox Publishing Indonesia.

Yusriyadi, 2010. Industrialisasi dan Perubahan Fungsi Sosial Hak Milik Atas Tanah. Yogyakarta: Genta Publishing. 